\title{
DOES SECURITIES REGULATION HINDER FINANCING SMALL BUSINESS
}

\author{
Gustav B. MargraF*
}

Many problems beset the small business enterprise that contemplates the raising of capital through long term debt or equity financing. The most serious obstacle to be overcome is the notorious lack of a market for securities of small companies. This problem is accentuated not only by the reluctance of people to invest in unknown small enterprises located at distant places, but also by the restrictions in state and federal laws upon the investment of funds held by such institutions as bank and insurance companies and by fiduciaries.

A second obstacle is the finding of a satisfactory medium for distribution of the securities. The services of the larger underwriting houses are generally unavailable because of the high cost of distribution in relation to proceeds from small issues. Often even the smaller firms are reluctant to assume the job. When an underwriter is found it is difficult to obtain a firm commitment for purchase of the securities and the issuer must run the risk of incurring substantial expenses without any assurance of the success of the offering.

To these and other obstacles is added the requirement of compliance with federal and state securities laws. This is by no means the least of the issuer's problems.

The extent federal and state regulation of the issue and sale of securities has hindered financing of small business has been the subject of much debate. There are those on the one hand who say that the federal registration process has greatly impeded and discouraged the public financing of small enterprises and new ventures. Others insist that the problems of financing small business are primarily economic rather than of legislative origin and that they have not been enhanced in any material respect by the Securities Act.

There are those too who feel that the state securities laws, the "blue sky" laws, have impeded financing of small business. Such charges are not so numerous, however, perhaps because the complainants have not had the forum for expression of their views that is provided by the perennial hearings in Congress which afford an opportunity for expression of any complaint at any time with the almost complete assurance that nothing will be done about it. Enough time has elapsed since the first blue sky law was adopted in IgIx to permit the securities industry to adapt its operations to the requirements of the laws. Accordingly they have come to be

*A.B., 1936, Southeast Missouri State Teachers College; LL.B., 1939, Duke University. Member of the New York and Missouri Bars. Contributor to legal periodicals. 
accepted as a workable and necessary protecting measure for the investing public.

Actually the real answer to the question lies between the two extreme points of view. Inevitably any measure which imposes restrictions will have a deterring effect upon the subject to which it relates. Whether the cause is real, as industry representatives contend, or fancied, as others suggest, the result is the same. Unquestionably, the securities laws have impeded some financings. The obstruction, however, is undoubtedly not so great as it is frequently represented to be. Certainly no insuperable barrier to small business financing has been created by the laws.

\section{Federal Security Regulation}

The federal security regulation with which the issuer of securities is concerned is embodied in the Securities Act of $1933^{1}$ as administered by the Securities and Exchange Commission (herein referred to as "S. E. C."). The Act does not prohibit the sale of speculative or unsound securities nor does it confer power on the S. E. C. to prevent such sale so long as the full truth is told. The Commission may not under the Act deny registration on grounds other than faulty or inadequate disclosure of information. ${ }^{1 a}$ In this respect the Act differs from some of the blue sky laws where power is given to the state regulatory authority to prevent sale of the security on grounds related to the soundness of the security. ${ }^{2}$

The restrictive effect of the Act lies not in any statutory prohibition on the sale of speculative securities but rather in other factors arising from its application which create conditions bearing upon the feasibility of small financing. These include principally factors relating to cost, time, liability and burden on the staff of small enterprises.

The Act does not apply to all financings. Where it does apply the restrictions are not always of the same degree. A number of provisions may be taken advantage of especially by small businesses to avoid the principal burdens of the Act.

The provision regarded by the S. E. C. as the most important from the standpoint of small issues ${ }^{3}$ is the exemption for transactions by an issuer not involving any public offering. ${ }^{4}$ The exemption extends only to the registration ${ }^{5}$ and prospectus ${ }^{6}$ requirements of the Act. ${ }^{\top}$ It does not relieve the issuer from civil liability imposed by Section 12 for sales in interstate commerce or through the mails by means of untrue statements or misleading omissions; nor does it relieve the issuer of Section I7 which makes unlawful the use of such means or other fraudulent devices. ${ }^{8}$

The principal difficulty with the use of this provision is that the area of exemp-

${ }_{4}^{1} 8$ STAT. 74 (1933), is U. S. C. (1940 ed.) \$77a et seq. (Hereinafter cited simply by Section.)

14 S. E. C. Release No. I, May 27, 1933; Hearings before the House Committee on Interstate and Foreign Commerce on Proposed Amendments to the Securities Act of 1933 and to the Securities Exchange Act of 1934 (hereinafter cited as "Hearings on Proposed Amendments"), 77th Cong., Ist Sess. (194I) 635; S. E. C. Tenth Annuar Report (1944) 3.

'Hearings on Proposed Amendments, 31, 36 .

Sec. $4(\mathrm{r})$.

Sec. $5(\mathrm{~b})$.

${ }^{3}$ Hearings on Proposed Amendments, 655.

Sec. 5(a).

Violators of this provision are subject to S. E. C. investigation [Sec. $20(a)$ ], injunction [Sec, $20(b)$ ], or criminal prosecution [Sec. 24]. 
tion which it affords has not been precisely defined. Indeed, because of the doubts attendant upon its application to a given situation issuers are reluctant to rely upon it except in very clear cases. An issue is not removed from the category of "public offering," for instance, for the reason alone that the offering is confined to the issuer's employees." Nor is it not a "public offering" simply because it is limited to security holders of the issuer. ${ }^{10}$

The distinction between a "public" and a "private" offering depends upon all the circumstances of the particular case. ${ }^{11}$ The General Counsel of the S. E. C. ruled in an early opinion that the determination of the scope of the exemption depends upon a number of considerations. ${ }^{12}$ These include the number of offerees (not actual purchasers) and their relationship to each other and to the issuer, the number of units offered, the size of the offering and extent to which a later public offering of all or part of the securities sold by the issuer is likely, and the manner of the offering, whether by direct negotiation by the issuer or by the use of machinery of public distribution.

This exemption is regarded by the S. E. C. as of particular importance to small business because the Commission feels that the most common source of capital for "really small business is from relatives, friends, and business connections." 13 This is undoubtedly true in many instances. The thought is controverted, however, by many expressions of industry representatives to the effect that there is little market for issues of small concerns and long term and equity capital must generally be obtained from a public issue. ${ }^{14}$ This would indicate the inadequacy of this exemption for general financing of small business because of the necessity of contacting large numbers of prospective purchasers to create a market for the securities.

A second provision in the Securities Act which may be a means of financing small businesses without encountering the impediments created by the Act is that relating to intrastate issues. ${ }^{15}$ This provision exempts "any security which is a part of an issue sold only to persons resident within a single State or Territory, where the issuer of such security is a person resident and doing business within,

'H. R. Rep. No. 1838, 73rd Cong., 2d Sess. (I934) 4I; S. E. C. Release No. 97, Part 6, Dec. 28, 1933.

${ }_{10}$ H. R. Rep. No. 152, 73rd Cong., Ist Sess. (1933) 25 ; S. E. C. Release No. 97, Part 5, Dec. 28 , 1933; S. E. C. v. Sunbeam Gold Mines Co., 95 F. (2d) 699 (C. C. A. 9 th, 1938). Cf. S. E. C. v. Federal Compress and Warehouse Co., U. S. Dist. Ct., W. Dist. Tenn., W. Div., Nov. 13, 1936, app. dis. without prejudice on motion of appellants, $88 \mathrm{~F}$. (2d) Ior 8 (I937).

${ }^{11}$ S. E. C. v. Sunbeam Gold Mines Co., 95 F. (2d) 699 (C. C. A. 9th, 1938); Aircraft Accessories Corp. v. Siebenthaler, Siebenthaler v. Aireraft Accessories Corp., U. S. Dist. Ct., W. Dist. Mo., Aug. 12, $194^{\circ}$ (unreported).

${ }^{13}$ S. E. C. Release No. 285 , Jan. 24, 1935.

${ }^{13}$ Hearings on Proposed Amendments, 655.

14 Hearings before Special House Committee on Post-War Economic Policy and Planning, 78th Cong., 2d Sess. (1944) 527, 533, 543; Fourth Report of House Special Committee on Post-War Economic Policy and Planning, H. R. ReP. No. 1855,78 th Cong., 2d Sess. (I944) 50; Senate Special Committee to Study Problems of Small Business, Sen. Comm. Print No. 15, 78th Cong., Ist Sess. (1943) 19. It is controverted also by statistics published by the S. E. C. showing that substantial amounts of offered securities of new ventures and small growing concerns remain unsold. Hearings on Proposed Amendments, 647.

${ }^{10}$ Sec. 3 (a) (II). 
or if a corporation, incorporated by and doing business within, such State or Territory."16 The basic theory of this exemption is that the offering will be confined to a single locality where a state blue sky commission has jurisdiction over the entire transaction and therefore is in a position to protect investors. ${ }^{17}$

Offerings made under this provision must be carried out with the greatest of care. The exemption is available only if the entire issue is sold to residents of the state wherein the issuer is incorporated and doing business. A single sale to a nonresident of that state will deny the exemption to the entire issue. ${ }^{18}$ It would be immaterial that the sale to the non-resident was made without use of the mails or instruments of interstate commerce, or that the seller was exempt, as to that specific sale, from the registration and prospectus requirements. ${ }^{10}$

For the exemption to be applicable the conditions must be met at the time of completion of ultimate distribution..$^{20}$ It is not sufficient that the conditions are met at the time of initial sale by the issuer to its underwriters or at the time of sale by the latter to distributing dealers. The securities are not considered as "sold" for the purpose of this section until they are in the hands of purchasers buying for investment and not with a view to further distribution or resale. ${ }^{21}$ Once this condition is met they may be resold, either directly or through brokers and dealers, to non-residents without affecting the exemption. ${ }^{22}$

Despite its limitations the intrastate exemption is important for small business financing. This is evident from the fact that hundreds of small issues have been sold under the exemption. ${ }^{23}$

By far the most important provision from the standpoint of small business financing is the section of the Act which confers upon the S. E. C. power to exempt small offerings. ${ }^{24}$ An amendment to this section was approved by President Truman on May ${ }_{5}$ of this year, raising the limit for offerings exempted under this provision from $\$$ roo,000 to $\$ 300,000 .^{25}$

The provision does not automatically exempt all issues up to $\$ 300,000$. It simply permits the S. E. C. to add to the exempt securities specified in the Act any class of securities as to which the Commission finds the requirements of the Act are not necessary in the public interest and for the protection of investors by reason of the small amount involved or the limited character of the public offering. The Commission may condition the exemption upon such terms as it deems necessary to protect the public and investors.

10 The exemption does not relieve the seller of civil liabilities under Scc. 12 (roughly, sale by untruthful statements) or the penalties provided for violation of Sec. I7 (fraudulent practices).

${ }^{17}$ Hearings on Proposed Amendments, 656.

${ }^{18}$ Opinion of S. E. C. Gen. Counsel, S. E. C. Release No. I459, May 29, 1937.

10 Ibid.

${ }^{20}$ Ibid.: H. R. REP. No. 1838 (Conf. Rep.) 73rd Cong., 2d Sess. (1934), 40; in the Matter of Brooklyn Manhattan Transit Corp., I S. E. C. I47 (1935).

${ }^{21}$ Opinion of S. E. C. Gen. Counsel, S. E. C. Release No. 1459, May 29, 1937.

22 Ibid. Such resales would be relevant to the question of exemption only in the evidentiary light which they would cast upon whether the securities had come to rest in the hands of resident investors.

${ }^{23}$ Hearings on Proposed Amendments, 656.

${ }^{25}$ Public Law 55, 79th Cong., Ist Sess. (1945), ch. 122.

2 Sec. 3 (b). 
Like other exemptions under Section 3 of the Act, this is not a complete exemption from all provisions of the Act. Section 12 , which imposes civil liability upon persons making sales by means of untrue statements or misleading omissions, and Section 17 , which makes it unlawful to sell securities by such means or by other types of fraud, are applicable to sales made under this exemption. The effect of the exemption is to permit the sale of securities without prior registration and with less complete disclosure than is required for registered securities. Civil liabilities are restricted to the seller and persons controlling the seller. The liabilities imposed upon others by Section Ir are inapplicable. ${ }^{26}$

The provision for exemption of small issues was the subject of much discussion at the hearings held in 194x by the House Interstate and Foreign Commerce Committee on proposed amendments to the Act. A number of representatives of investment bankers and prospective issuers appeared and testified in favor of raising the maximum limit permitted by the exemption. ${ }^{2 \pi}$ Proposals made by industry representatives ranged from $\$ 500,000$ to $\$ 1,000,000 .^{28}$ The S. E. C. was agreeable to an increase to $\$ 300,000 .^{29}$ When the matter was before Congress again in the bill which was finally passed ${ }^{30}$ the Commission again approved the amendment to raise the limit to $\$ 300,000$, although taking the position that broadening the exemption would not diminish the cost of small business financing to a substantially significant degree. $^{31}$

On May 22, 1945, the S. E. C. amended its regulation to implement the statutory change and raise the exemption limit to $\$ 300,000$ for issues qualifying under the regulation. ${ }^{32}$ The Commission emphasized that its action was of a temporary nature and was not to be construed as indicating a final determination by it that the requirements set forth in the new regulation were regarded as adequate in the case of all issues up to $\$ 300,0000^{33}$ The Commission cautioned that on the experience with the old regulation and in view of conditions now developing, it might be necessary to modify the temporary regulation or prescribe additional rules for offerings up to $\$ 300,000$.

The $\$ 300,000$ exemption is applicable to all securities except (a) securities of investment trusts or investment companies subject to the Investment Company Act of 1940 , (b) voting trust certificates, (c) fractional undivided interests in oil or gas rights and similar interests in other mineral rights, (d) certificates of interest, (e) securities of foreign issuers, (f) securities of issuers barred because of federal or state stop order or court proceedings, and $(\mathrm{g})$ certain securities as to which a registration statement has been in effect. ${ }^{34}$ The exemption is available only if the

${ }^{30}$ These include all persons who sign registration statements, persons who are or are about to become directors or partners, certain experts who prepare or certify parts of registration statements or reports or valuations used therein, and underwriters of the security.

${ }^{27}$ Hearings on Proposed Amendments, 601-68I.

${ }^{28} I d$. at $604,618,621,635$.

${ }^{20} \mathrm{Id}$. at 676 .

${ }^{30}$ S. 62, 79th Cong., Ist Sess. (1945), bill introduced by Sen. Vandenberg.

${ }^{31}$ Sen. Rep. No. 123, 79th Cong., ist Sess. (1945); H. R. Rep. No. 489, 79th Cong., Ist Sess. (1945). See also, S. E. C., Tenth Annual Rep. (April 21, 1945) 6, 7.

${ }^{82}$ S. E. C. Release No. $3066 . \quad{ }_{33}^{3}$ Ibid. $\quad{ }^{34}$ S. E. C. Reg. A, Rule 221. 
aggregate offering price of the following does not exceed $\$ 300,000$ : (I) All securities of the issuer which under the exemption are proposed to be offered presently, are currently being offered, or have been previously sold pursuant to an offering commenced within one year prior to the commencement of the proposed offering, and (2) all securities of the issuer neither registered nor exempt nor sold in an exempt transaction which were sold within one year prior to the commencement of the proposed offering. ${ }^{35}$ Securities offered to a single holder of the majority of the voting stock of the issuer in connection with a pro rata offering to stockholders, and securities exchanged for outstanding securities, claims or property in connection with a bona fide recapitalization or reorganization need not be included in determining the amount of securities which may be offered pursuant to the exemption. ${ }^{30}$ An offering may be made pursuant to the exemption even though it is contemplated that after the termination of the offering an offering of additional securities will be made. ${ }^{37}$

In lieu of compliance with the registration and prospectus requirements of the Act there is required to be filed with the S. E. C. at least five days ${ }^{88}$ (Sundays and holidays excluded) prior to the offering a letter of notification containing the following information: (I) Names and addresses of the issuer, its directors and offcers, persons making the offering, and principal underwriters; (2) title and principal amount or number of shares proposed to be offered, offering price and aggregate amount, and aggregate amount of all securities of the issuer offered to the public within one year by the person filing the notification; (3) approximate offering date; (4) list of jurisdictions in which it is proposed to sell the securities; and (5) the purposes for which the net proceeds from the securities are to be used. ${ }^{30}$

Three copies of all selling literature proposed to be used at the commencement of the public offering or intended to be sent thereafter to more than ten persons must be filed with the S. E. C. at least five days prior to its use. ${ }^{40}$ The material filed pursuant to this requirement is required solely for the information of the Commission to aid it in enforcing Section $x_{7}$ (relating to practices made unlawful) and not for the purpose of enabling the Commission to cite any deficiency in the information contained in the material.

The selling literature required to be filed with the Commission must contain on the first page a statement to the effect that because the securities are believed to be exempt from registration they have not been registered with the S. E. C. ${ }^{41}$ The

${ }^{36}$ S. E. C. Reg. A, Rule $220(a)$. The Regulation also permits offerings up to $\$ 100,000$, similarly limited, to be made by a person controlling, controlled by, or under common control with the issuer. However, the aggregate offering price of the securities of the issuer and those of the person controlling, controlled by, or under common control with the issuer may not exceed \$300,000 in any twelve-month period. S. E. C. Reg. A, Rule 220 (d).

${ }^{88}$ S. E. C. Reg. A, Rule 220 (c). $\quad{ }^{37}$ S. E. C. Reg. A, Rule 220 (c).

${ }^{38}$ Before the amendment of May 22 the period was 24 hours. 30 S. E. C. Reg. A, Rule 222.

${ }^{10} \mathrm{~S}$. E. C. Reg. A, Rule 223 (a). The period formerly was twenty-four hours. Communications which do no more than identify the securities, state the price and state by whom orders will be executed need not be filed.

${ }^{11}$ S. E. C. Reg. A, Rule 223 (b). 
statement must set out also that such exemption, if available, does not indicate that the securities have been either approved or disapproved by the Commission or that the Commission has considered the accuracy or completeness of the statements in the selling literature.

The only requirement with respect to the selling literature used in connection with offerings under the exemption is that it state the person for whom the securities are being offered, the number of units being offered, the amount per unit and aggregate of underwriting discounts or commissions or, if none, the amount per unit and aggregate of expenses incurred or to be incurred in connection with the offering, and the purposes for which the net proceeds from the securities are to be used. ${ }^{42}$

A further step was recently taken by the S. E. C. to broaden the scope of the exemption permitted by Commission regulation. On March 24 of this year a new regulation was announced exempting offerings up to $\$ 100,000$ of assessable shares of domestic mining corporations. ${ }^{43}$ The Commission commented that it had received suggestions of various mining men, mining organizations, attorneys, accountants, and others who were furnished draft copies of the regulation for review and criticism. A number of objections were raised on the basis that the regulation was inadequate to safeguard the interest of purchasers. The Commission stated that in view of this problem it was not without some misgivings in adopting the regulation and it was therefore adopted on a trial basis. If abuses develop adversely affecting the public interest the regulation will be modified or rescinded.

In the case of assessable shares of mining corporations the sum of the aggregate offering price of the shares proposed to be offered, the aggregate offering price of the issuer's securities currently being offered publicly without registration and the aggregate sales price of the issuer's securities sold without registration to the public for the issuer's account within the preceding year may not exceed \$100,000.44 The aggregate offering price of the issuer's securities offered to the public without registration in each successive yearly period plus the amount received in each such period as a result of all assessments may not exceed $\$ 100,000 .{ }^{45}$ Not more than one offering may be commenced by the issuer under the exemption in any period of one year. ${ }^{46}$

A prospectus must accompany the initial solicitation of persons to whom assessable shares of mining corporations are offered. ${ }^{47}$ The prospectus must contain substantially more information than is required in selling literature used in connection with offerings of other types of securities under the exemption. ${ }^{48}$

The issuer of assessable shares of mining corporations is required also to send, at the time of each assessment levied after the commencement of the offering, to

${ }^{43}$ S. E. C. Reg. A, Rule 223 (c).

${ }^{4} 3$ S. E. C. Reg. A-M, Rule 240; Securities Act Release No. 3051, March 24, 1945. This exemption has not been amended to take advantage of the newly enacted $\$ 300,000$ limit for exemptions permitted by S. E. C. regulation.

“S. E. C. Reg. A-M, Rule 240 (a).

${ }^{10} \mathrm{~S}$. E. C. Reg. A-M, Rule $240(\mathrm{c})$.

${ }^{45}$ S. E. C. Reg. A-M, Rule $240(b)$.

${ }^{48} \mathrm{Ibid}$.

"S. E. C. Reg. A-M, Rule 240 (e). 
each holder of the class of security being offered, a notice of assessment accompanied by a statement containing certain information relating to amount of funds received during the last two years, purposes for which the funds were used, developmental status and ore reserve postion of the property, consideration received for shares issued for other than cash, aggregate amount of current assessment, issuer's intended use of the amount realized and other available funds, issuer's intention with respect to further assessments during the following year, and the material provisions, statutory or otherwise, applicable to assessments on the shares being offered. ${ }^{40}$

The exemption for corporate offerings up to $\$ 300,000$ and assessable mining shares up to $\$ 100,000$ is of very real benefit to small businesses. The filings required to be made are extremely simple as compared with registration of non-exempt securities. Under no circumstances could it be said that the conditions imposed are unduly burdensome.

The practicability of the small issue exemption is demonstrated by the fact that during the twelve months ending June 30, 1944, 427 Letters of Notification were filed with the S. E. C. pursuant to Regulation A.50 These, with the 209 amendments to the Letters which were filed, represent aggregate offerings of $\$ 21,933,994^{61}$

The statutory amendment raising to $\$ 300,000$ the amount of an issue of securities which may be exempted by Commission regulation and the recent amendments to the regulations to implement in part this statutory change have gone far to answer the complaints that the Securities Act is a burden on small financing. In reporting the bill the Senate Committee on Banking and Currency stated that the amendment was desirable, particularly in the interest of small business and that it would enlarge the opportunity of small business to finance itself. ${ }^{52}$ The Committee noted that the Special Senate Committee on Post-War Economic Policy and Planning had reported that "the act makes equity financing of small businesses practically impossible in that the floating of new small security issues is so troublesome and expensive that small businesses are unwilling to undertake the burdensome routine." ${ }^{\text {"3 }}$ This statement echoes the complaints made time and again by representatives of industry in hearings before various Congressional Committees and elsewhere. ${ }^{54}$ However exaggerated it may be there is no doubt that the raising of the exemption will be a welcome aid to small business financing.

The most frequently voiced objection to the Securities Act as it affects small businesses is that it contributes to the disproportionately high cost of small financ-

- ${ }^{\circ}$ S. E. C. Reg. A-M, Rule 240 (g).

${ }^{n}$ S. E. C. TEntr Annual Report (1945) 7. This, of course, was before the exemption was raised from $\$ 100,000$ to $\$ 300,000$.

${ }^{51} \mathrm{Ibid}$.

${ }^{5}$ Ibid.

${ }^{62}$ SEN. REP. No. 123, 79th Cong., 1st Scss. (1945).

"Hearings on Proposed Amendments: statements of Arthur G. Davis, Field Secretary, Investment Bankers Assn. of America, 603, 613; Rush S. Dickson, President of R. S. Dickson \& Co., 616; Paul W. Loudon, representing group of Minnesota investment bankers, 624; Frayser Jones, Nat. Assn. Mfgs., 638; Wm. B. Putney, 3d, Comm. for Re-employment of Men and Money, Commerce and Industry Assn. of N. Y., Inc., 649. Statement of Ferdinand Eberstadt before House Special Comm. on Post-War Economic Policy and Planning, May 3I, 1945. 
ings. There is no dissent from the fact that the cost of offering equity securities and long term debt is excessively high for small businesses. ${ }^{55}$ The costs increase in relation to receipts to the company as the size of the issue decreases. There is disagreement, however, over the factors responsible for the heavier costs.

Representatives of industry have attributed the excessive costs of small financings to the registration requirements of the Securities Act. ${ }^{56}$ Witnesses at the House Interstate and Foreign Commerce Committee hearings in I94I on proposed amendments to the Securities Act stated that a minimum cost of $\$ 5,000$ must be incurred even in the smallest registration if the services of competent attorneys and accountants are to be obtained. ${ }^{57}$ It was testified also that the fair average cost of registering a $\$ 200,000$ issue would be $\$ 6,000 .^{58}$ These estimates were controverted by the present Chairman of the S. E. C., Mr. Purcell, who cited nine instances of registrations of issues of Motors Securities, Inc., of Shreveport, La., in amounts of $\$ 200,000$, $\$ 700,000$ and $\$ 1,000,000$, where the registration expenses were only $\$ 320$ each, except in one case, where the expense was $\$ 45^{0 .} .^{50}$

One witness testified that where an issue of from $\$ 200,000$ to $\$ 500,000$ is registered the cost is about double that incurred when only state qualification is involved. $^{00}$ He cited an example of an offering of around \$200,000 not involving federal registration, where the cost was $\$ 2,000$ for printing, legal and engineering fees and related expenses. This compared with a cost of $\$ 6,500$ for similar expenses in connection with a federally registered offering of $\$ 235,000$.

Another witness pointed out that it is almost impossible to obtain a firm commitment by an underwriter to purchase an issue of securities before registration is substantially completed. The issuer therefore must assume all the costs of registration without any assurance that it will be able to recoup its expenses from the sale of its securities. The situation is further aggravated by the fact that the small issuer usually is in urgent need of additional working capital or it would not be seeking to sell its securities. If the costs of registration are not recovered the company's capital may be seriously depleted. Many small companies are unwilling to run this risk. ${ }^{61}$

The S. E. C. has taken the position that the problems of financing small business were neither created nor increased in any material respect by the Securities

vo Small Business: Access to Capital, Sen. Comm. Print No. 15, 78th Cong., Ist Sess. (1943) 2, I9; Hearings before the Special House Comm. on Post-War Economic Policy and Planning, 78 th Cong., 2d Sess. (1944) 46r; Report of Small Bus. Advisory Comm. to Sec. of Commerce (May 28, r945) 18.

${ }^{60}$ Hearings on Proposed Amendments, 108, $116,117,129,603,611,616,617,623-626,637,638$, 648. The principal complaint in hundreds of letters received by Rep. Wadsworth was said to be that the costs of registration were too high and burdensome. Id. at $648,65 \mathrm{x}$.

${ }^{67} \mathrm{Id}$. at 617 .

10 Id. at 672. Mr. Purcell acknowledged that these were not average figures. He insisted, however, that an estimate of $\$ 5,000$ as minimum expenses arising from registration is much too high.

${ }^{\circ 0}$ Hearings on Proposed Amendments, 625 (Mr. Loudon).

o1 Id. at 648,649 . The witness observed that while underwriting commissions are heavier than registration costs they do not contribute to the risk assumed by the small issuer because they are paid only if the securities are sold. 
Act. ${ }^{62}$ The Commission's contention is that the problems are primarily of an economic rather than a legislative nature. ${ }^{63}$ Statistics compiled by it leave no room for doubt that the primary reason for the higher cost of small offerings is to be found in the underwriting fees. On the basis of a study covering the years 1938 through 1940 the Commission estimated that the average cost of registration per $\$$ 100 of securities in offering under $\$ 1,000,000$ during those years was about 92 cents. ${ }^{04}$ The average underwriters' compensation in such cases 'was $\$ \mathrm{r} 2.03{ }^{65}$

A fairly reliable indication of the costs of small financings may be obtained from statistics published from time to time by the S. E. C. The Commission's Tenth Annual Report, published in April of this year, contains a table showing the division of the cost of flotation of registered equity securities of small companies between distributors' compensation and other expenses for the period from January I, $193^{8}$ to June $30,1944^{66}$ For all equity securities of the companies with assets of less than $\$ \mathrm{r}, 000,000$ included in the study the total cost of flotation amounted to 21.6 percent of gross proceeds. Of this amount 19.7 percent represented compensation to distributors and I.9 percent other expenses. ${ }^{67}$ In the case of preferred stock the total cost of flotation was 19.3 percent, 17.5 percent being attributable to distributors' compensation and 1.8 percent to other expenses. For common stock the total cost was 22.I percent, 20.2 percent for distributors' compensation and $\mathrm{x} .9$ percent for other expenses. ${ }^{68}$

Of course, not all of the expenses not attributable to distributors' compensation are the result of registration requirements of the Act. The only expense for which the Act is wholly responsible is the registration fee of one one-hundredth of one percent of the gross proceeds. Expenses for printing and engraving, legal, accounting, engineering fees and certain other miscellaneous expenses are partly attributable to registration. Those not at all attributable to the Act include exchange listing, federal revenue stamp tax, state qualification and fees of transfer agents.

Statistics compiled by the S. E. C. indicate that for registered equity securities of companies with assets of less than $\$ \mathrm{r}, 000,000$ the printing and engraving expenses amounted to 0.32 percent of expected gross proceeds from sale of the securities, legal expenses, 0.70 percent, accounting expenses 0.29 percent, and engineering expenses, 0.34 percent. $^{69}$ Thus it appears, for example, that printing expenses, about which

${ }^{62}$ Testimony of Mr. Purcell, Hearings on Proposed Amendments, 658.

${ }^{\circ}$ Ibid.

65 The average registration and compensation expenses per \$xoo of securities were, respectively, for issues under $\$ 100,000, \$ 1.16$ and $\$ 13.03 ; \$ 100,000-\$ 249,000, \$ 1.07$ and $\$ 11.59 ; \$ 250,000-\$ 499,000, \$ 0.91$ and \$13.66; and \$500,000-\$999,000, \$0.81 and \$ro.98. Id. at 675 .

${ }^{\circ}$ Table A-6. The table is published also in S. E. C. Statistical Series Release No. 744, October 22, 1944.

${ }^{87}$ For companies with assets between $\$ \mathrm{r}, 000,000$ and $\$ 5,000,000$ the figures were $15.8 \%, 14.0 \%$ and $1.7 \%$, respectively.

${ }^{88}$ For companies with assets of from $\$ 1,000,000$ to $\$ 5,000,000$ the costs were: prefarred stock, $12.5 \%$ (total cost), $x 1.0 \%$ (distributors' compensation) and $1.5 \%$ (other expenses); common stock, $17.5 \%$, $15.6 \%$, and $1.8 \%$, respectively.

${ }^{\circ 0}$ S. E. C. Statistical Release No. 744, Oct. 22, 1944, Table 4. These figures are for the period from Jan. $x, 1938$ to June 30, r944. They are based upon instances where such expenses actually were incurred and are not aggregate figures for all issues regardless of whether an expense of the type noted 
many complaints are heard, actually are a very small part of the total cost of small business financings.

The cost of bond financing is substantially lower than that of equity financing. An S. E. C. study published in 1940 shows that for the period 1935 through $193^{8}$ the total cost of bond issues for companies with assets under $\$ 1,000,000$ included in the study was 9.6 percent of gross proceeds. ${ }^{70}$ Compensation to distributors accounted for 7.7 percent and other expenses were responsible for I.9 percent. For companies with assets between $\$ 1,000,000$ and $\$ 5,000,000$ the figures for bond financing were 6.2 percent (total cost), 4.5 percent (compensation to distributors) and I.7 percent (other expenses). ${ }^{71}$ The expenses of preferred stock of companies of comparable size were: assets under $\$ I, 000,000,15.9$ percent (total cost), I4.6 percent (compensation to distributors) and I.3 percent (other expenses); assets between $\$ 1,000,000$ and $\$ 5,000,000$, I3.5 percent, I2.0 percent and 1.5 percent, respectively. ${ }^{{ }^{2}}$

Upon the basis of statistics such as these the S. E. C. contends that the principal deterrent to small business financing is the amount required to be paid as compensation to distributors of the securities and that the solution to the problem lies in finding a way to reduce such compensation. ${ }^{73}$ Representatives of industry counter with the argument, however, that businessmen think in terms of dollars and cents while the Commission is thinking in terms of abstract percentages. It is said that "the businessman who is obliged to spend ten or twenty or fifty thousand dollars to defray the costs of registration finds little consolation in the thought that those thousands of dollars pouring out of the company's treasury are only one-half of $x$ percent of the amount of securities being offered." "4

Closely related to the cost of financing is the complaint that the registration procedure unduly delays public offerings. ${ }^{75}$ The Securities Act originally required a twenty-day period after filing before the registration statement could become effective. ${ }^{70}$ The Act was amended in I940, however, to permit the Commission to accelerate the effective date and allow registration statements to become effective as

was incurred. Such aggregate figures are contained in the Commission's Tentra AnNuar Report (I945) Table A-7, and in Statistical Release No. 744, Table 3. The tables contain similar figures for companies with assets of between $\$ 1,000,000$ and $\$ 5,000,000$ and for all companies with assets of under $\$ 5,000,000$. Broken down between preferred stock and common stock for companies with assets under $\$ 1,000,000$, the figures are: printing and engraving-preferred $0.28 \%$, common $0.33 \%$; legal-preferred $0.97 \%$, common $0.64 \%$; accounting-preferred $0.41 \%$, common $0.26 \%$; engineering-preferred $0.57 \%$, common $0.11 \%$.

${ }^{70}$ Cost of Flotation for SMali. Issues, I925-I929 and 1935-I938 (Report of Research and Statistics Section of Trading and Exchange Division to S. E. C., I940) Table 5.

${ }^{11}$ Ibid.

${ }^{72}$ Ibid. Table 4 contains statistics for bonds and preferred stock by size of issue. The sizes are broken down into categories of under $\$ 250,000, \$ 250,000-\$ 499,000, \$ 500,000-\$ 749,000, \$ 750,000-$ $\$ 999,000$, and various categories above $\$ I, 000,000$. The study includes statistics relating to cost of bond and preferred stock flotations by industry, for utilities and for companies other than utilities, by method of offering, by yield, and a breakdown of expenses other than distributors' compensation by size of issue. In each instance the study includes a comparison of expenses for the I925-r929 period with those of the $1935-193^{8}$ period, showing that cost changes in the latter period have operated to the disadvantage of small issues. $I d$. at 9 .

${ }^{73} I d$. at 8 .

74 Hearings on Proposed Amendments, 648 .

${ }^{78}$ Sec. $8(a)$. 
soon as they could be examined to determine whether the requirements of the Act were met. ${ }^{77}$ An amendment filed prior to the effective date starts the period running again unless it is filed with the consent of or pursuant to an order of the Commission. ${ }^{78}$

The complaint of delay is not directed at the statutory waiting period. The Commission has been most cooperative in exercising its acceleration powers to reduce the impact of this provision. This has been done as readily for small issues as for large ones. However, many companies have found it impossible to comply with the requirements relating to registration without encountering substantial delays. It has sometimes been the experience that by the time the delays have been overcome the market has slipped away and the securities cannot be sold. ${ }^{70}$ This has acted as a deterrent to some companies that have been unwilling to run this risk.

Another criticism often directed at the Securities Act as it affects small business financing is the burden it places upon the staff of small issuers. ${ }^{80}$ The problem is much more severe for small companies than for large ones. The management personnel of the former usually consists of a very few persons. The time which they must spend in the preparation of the registration statement often interrupts the normal business of the issuer, with a resulting loss of profits. A loss of this kind, of course, is not susceptible of measurement.

The Commission is not unaware of the inconveniences experienced in complying with the registration requirements of the Act and from time to time has taken steps to lighten the burden. Thus, in October, I94I, Form S-2 was adopted to facilitate the registration of securities of small businesses. This form eliminates unnecessary duplication between registration statements and prospectuses and is generally available to registrants who do not have active subsidiaries, who are not successors to previously established businesses, and who have not been involved in insolvency proceedings for three years. ${ }^{81}$ Only recently the Commission adopted a new simplified form, Form S-II, for registration of shares of exploratory mining corporations. $^{82}$ Among other things the form dispenses with the requirement for certification of financial statements by independent accountants. On June Ir, I945, the Commission adopted Form S-r2, which may be used by companies not advanced beyond the development stage that (a) do not have or intend to have active subsidiaries, (b) have not recently been or do not intend to be involved in successions to other businesses and (c) have no long term debt. It is expected that the form will be of substantial assistance to newly organized small companies and those to be organized in the post-war period. Other forms have been adopted in recent years to simplify the registration procedure.

${ }_{77} 54$ Stat. 857 (1940) (Public Law No. 768, Title III, 76th Cong., 3rd Sess.).

78 Sec. 8(a).

${ }^{70}$ Hearings on Proposed Amendments, 624.

${ }^{80}$ Id. at 603, 626, 638,649; Hearings before Special House Comm. on Post-War Economic Policy and Planning, 78th Cong., 2d Sess. (1944) 531 .

${ }^{81}$ Hearings on Proposed Amendments, 656.

${ }^{82}$ S. E. C. Securities Act Release No. 305x, March 24, 1945. 
A further deterrent to small business financing is the fear of undue liabilities. ${ }^{83}$ This, in fact, has sometimes been said to be perhaps the most important factor of all. ${ }^{84}$ Such fear was widespread shortly after the Act was passed, but experience has shown it to be practically groundless. The S. E. C. has reported that a search of court records covering a period of eight years reveals that there were less than two dozen actions under all three of the civil liabilities of the Act. ${ }^{85}$

A number of other complaints have been made by small businesses. Some relate to such things as sales resistance engendered by the appearance on prospectuses of information disclosing the size of underwriting discounts and commissions. Some persons have objected also to disclosing to business competitors information respecting contractual arrangements. Such factors undoubtedly may affect adversely the sale of securities in individual instances, but the effect on the whole is probably fairly insignificant.

\section{State Security Regulation}

All states except Nevada have a law relating to the sale of securities. ${ }^{86}$ In some instances the law is brief and contains a minimum of regulation. In others the law is complex and regulates in detail the issue and sale of securities. In many states the regulation goes far beyond that of the Securities Act of I933 and confers upon the regulatory authority broad powers to prohibit the sale of securities on grounds related to the soundness of the business enterprise and the security.

In spite of the scope of state regulation the charges have not been numerous that the blue sky laws obstruct the financing of small business. The laws, with a history extending twenty-two years beyond that of the Securities Act, have generally been found to be workable and have come to be accepted as a necessary part of our legal system. Even some of the most ardent proponents of relaxation of the Securities Act with respect to small issues support their position by suggesting that the blue sky laws will adequately safeguard the interests of investors. ${ }^{87}$ Implicit in this is an acknowledgment that the state laws are not unduly obstructive.

The most widely adopted type of law is that following generally the pattern of the Uniform Sale of Securities Act. ${ }^{88}$ Twenty-one states have blue sky laws incorporating generally the substance of the Uniform Act. These are Alabama, Florida, Georgia, Illinois, Indiana, Iowa, Kansas, Kentucky, Louisiana, Michigan, Minnesota, Missouri, North Carolina, Ohio, Oklahoma, Oregon, South Carolina, South Dakota, Utah, Vermont and Wisconsin. The laws vary somewhat in form

${ }^{83}$ Hearings on Proposed Amendments, 603, 623.

86 Id. at 623 .

${ }^{85}$ S. E. C. Tenth Annual Report (1945) xii. According to the Commission not more than five suits resulted in recovery by the plaintiffs.

${ }^{80}$ There is no local securities law for the District of Columbia.

${ }^{87}$ Hearings on Proposed Amendments, 608.

${ }^{88}$ It will not be necessary for the purpose of this article to treat in detail the requirements and exemptions of the laws of each state. The present purpose is to give a general picture of the effect of state security regulation upon small business financing. Accordingly, citations to individual laws will be omitted. References to laws of the several states are to the securities laws of the respective states. 
and occasionally in certain substantive provisions, but the general import is substantially the same for all.

The result sought by this type of law is to facilitate the marketing of securities of unquestionable soundness without burdensome formalities while at the same time protecting the public against fraud and unsound securities. To this end the laws contain exemptions for types of issues going far beyond the exemptions in the Securities Act of r933. The exemptions include, inter alia, securities of public utilities subject to regulatory supervision as to rates or the issuance of their securities, and securities listed on the major stock exchanges and other recognized exchanges, as well as securities senior to such listed securities. ${ }^{89}$ There is also generally an exemption for negotiable promissory notes and commercial paper issued within a specified period after the date of sale (usually around three months) and maturing within a fixed time (ranging from six months to two years)..$^{00}$

There are also provisions exempting certain types of transactions. Such exemptions of interest to small businesses include distributions by a corporation of securities to its security holders as a stock dividend or other distribution out of earning or surplus; issuance of securities to security holders or other creditors of a corporation in a bona fide reorganization, either in exchange for the securities or claims of such holders or partly in exchange and partly for cash; and the issuance of additional capital stock of a corporation sold or distributed by it among its own stockholders exclusively, where no remuneration is paid in connection with the sale or distribution. The exempt transactions generally include also sales of securities to banks, savings institutions, trust companies, insurance companies, corporations, brokers and dealers. Included also is the transfer or exchange by one corporation to another of the securities of each in connection with a consolidation or merger. Finally, there is usually an exemption for subscriptions within a state for stock prior to incorporation under the laws of that state, when no expense is incurred and no remuneration is paid in connection with the sale and disposition of the securities. ${ }^{00}$

For going businesses with a sound earnings history the laws patterned along lines of the Uniform Act generally provide for a simple short form of registration called "registration by notification." This may be availed of when the issuer owns a business or property which has been in continuous operation for a designated period (usually three to five years) and has had for a required number of years (usually not less than two years) a specified ratio of earnings to debt charges and dividend requirements. The ratio is usually one and one-half times interest charges, in the case of an offering of bonds, and one and one-half times dividend requirements, in the case of an issue of preferred stock. Where common stock is being offered the issuer is customarily required to have earned an amount applicable to

\footnotetext{
${ }^{80}$ Not all the laws in this category have all the exemptions discussed here.

${ }^{\circ 0} \mathrm{~A}$ number of states whose laws do not follow the pattern of the Uniform Act have some or all of these exemptions.

${ }^{30 \mathrm{a}}$ Sometimes there is an exemption for sales of stock in any domestic corporation of the state, if no commission or remuneration or similar selling expense is included in the sale. E.g., N. C., GEN. STAт. (1943) \$78-4(7).
} 
common equal to five or six percent of all outstanding stock of equal rank.

There are also provisions for registration by notification of bonds or notes secured by mortgages meeting certain requirements.

When the process of registration by notification is available the procedure for registration is simple and inexpensive. It usually involves the filing of a notice stating simply the name, location and place of incorporation of the issuer, brief description of the security, amount of securities to be offered in the state, brief statement of the facts showing that the security falls within the class for which the simplified registration is provided, and a statement of the offering price. Financial information relating to the issuer is often called for, and a copy of the offering circular generally is required. The securities in most instances are deemed registered upon the filing of the notice.

If the security is not exempt or sold in an exempt transaction, and if the procedure of registration by notification is not available, it must be registered by the more complicated process of "registration by qualification." Registration by qualification usually involves the filing of fairly complete information about the issuer and the securities to be offered. Although this procedure is considerably more troublesome than registration by notification, it is not in the least comparable with federal registration. No "registration statement" is required and no substantial expenses for printing must be incurred.

In addition to information about the business of the issuer and the securities to be offered, the application for registration by qualification usually calls for a recent balance sheet of the issuer (normally as of within 60 or 90 days) and an income statement for the last fiscal year. Information is required respecting the offering price and the maximum commissions or other remuneration to be paid in connection with the sale, and a detailed statement must be made of the items of cash, property, services, patents, good will and other consideration for which securities have been or are to be issued in payment. A certified copy of the charter and by-laws must be filed.

The burden of state qualification was recently alleviated somewhat by the adoption in a number of states of a simplified uniform application form. ${ }^{01}$ The form was prepared by the National Association of Securities Commissioners and adopted by that body in r94r. It may be used only for securities registered under the Securities Act of r933 which must be qualified under state laws otherwise than by notification. The form may not be used for oil, gas or mineral securities, securities which are essentially certificates of interest in securities, American certificates against foreign issues, voting trust certificates, certificates of deposit, securities sold or modified in the course of a reorganization requiring a special form or process of registration under the Securities Act of I933, or securities of any company primarily engaged in the business of investing or reinvesting in securities other than an open-end man-

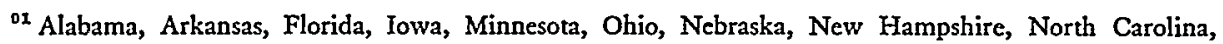
Rhode Island, Tennessec, Texas and Virginia. Certain variations are necessitated by the laws of some states.
} 
agement investment company which does not issue periodic payment plan certificates and which is not the sponsor or depositor of a company issuing such certificates. The uniform form is by no means an answer to the complications involved in state qualification, but it is a step toward simplification.

Most important from the standpoint of the small company is the power granted to the regulatory body to deny registration if it finds that the issuer's business is based upon unsound business principles. (The Securities and Exchange Commission has no such power.) The regulatory authority is also empowered to deny registration, and in the case of registration by notification, suspend registration, if it finds that the sale of securities would tend to work a fraud upon the purchaser.

The regulatory authority may also revoke registration, both of securities registered by notification and by qualification, if it appears that the issuer is insolvent, has violated any provision of the securities law or order of the commission, has engaged or is about to engage in fraudulent transactions, is in any other way dishonest or has made fraudulent representations in any literature that has been distributed concerning the issuer or its securities, is of bad business repute, does not conduct its business in accordance with law, or that its affairs are in an unsound condition or the enterprise or business is not based upon sound business conditions.

The statutes commonly provide that if the securities are to be issued for any patent right, copyright, trademark, process, formula, goodwill, organization or promotion fees or expenses, going concern value or other intangible assets the Commission may require the securities issued in such payment to be delivered in escrow until all other stockholders who have paid for their stock in cash have been paid dividends aggregating a required amount (usually around six percent). In the case of dissolution or insolvency while the securities are held in escrow, the owners may not participate in the assets until after the owners of all other securities have been paid in full.

The regulatory authority is usually given power to obtain an injunction against fraudulent practices. Sales in violation of the law are voidable at the election of the purchaser, and civil liabilities are imposed upon the seller and directors, offcers and agents of the seller who participated in the sale. Finally, criminal sanctions are imposed for violations of the law.

A further burden upon non-resident issuers is the requirement in many of the laws that the issuer file consent to service of process, regardless of whether the application for qualification of the securities is filed by the issuer or a registered dealer. This is required in the majority of the blue sky laws, regardless of the type of law.

In many states also the issuer is required to register as a dealer in securities if it sells the securities itself or through agents. A number of states, however, do not impose this requirement upon companies selling securities of their own issue.

It is important to note that in most states registration of securities may be made either upon application of the issuer or a registered dealer. 
The discussion of state regulation thus far has related mainly to the blue sky laws of the twenty-one states following the pattern of the Uniform Sale of Securities Act. A second type of statute exists in the seven states of Arizona, Arkansas, Idaho, Mississippi, Montana, North Dakota and Tennessee. This is the obsolete form of "investment company" statute. In this type of statute the classes of exempt securities and exempt transactions are very narrow. ${ }^{92}$ The effect of this type of statute is to require registration of securities in much the same manner as registration by qualification under the statutes of the Uniform Act type. The powers of the regulatory authority are generally as broad as in the case of the states following the Uniform law. The authority usually has power to determine, inter alia, whether the business of the issuer promises a fair return on the investment represented by the securities and to deny registration if this condition is not met.

The "investment company" type of statute generally permits qualification of the securities by registered dealers if the issuer does not itself apply. ${ }^{93}$

A third type of blue sky law is the fraud type which exists in Connecticut, Delaware, Maryland, New Jersey and New York. This is the simplest form of state security law and involves the minimum of regulation. No provision is made for registration of securities. ${ }^{94}$ The sole objective of the statute is prevention of fraud, and the regulatory authority or attorney general is given authority to secure injunctions to accomplish this end.

Closely related to the fraud type of statute are the laws of Maine and New Hampshire. In both states dealers are required to register and the securities commissioner may prevent sales of securities on grounds of fraud or inadequate disclosure. In Maine dealers may be required to file information respecting the securities. The New Hampshire law requires dealers to qualify securities prior to sale by filing information with the commissioner. The New Hampshire commissioner may prevent sales also if he is of the opinion that there is serious financial danger to the purchaser.

The remaining twelve states have a variety of statutes which do not fit closely into any of the general types. The California law has few exemptions but the registration requirements apply only to sales by a company of securities of its own issue. $^{95}$ Hence, where the securities are not issued within the state sales may be made by registered brokers without an issuer's permit having been obtained. In Colorado registration is required prior to sales of non-exempt securities, but the exemptions are fairly broad. The Massachusetts law provides for qualification by

\footnotetext{
02 This is not true in the case of Idaho, Mississippi and Montana, where the exemptions have been enlarged to follow generally those of the Uniform Act.

${ }^{8}$ The Tennessee law does not contain such a provision and makes it a misdemeanor for any person to sell securities of a company that has not complied with the law. This type of statute has discouraged the sale in the state of many sound issues of both large and small companies and has deprived the public of an opportunity to purchase securities of unquestionable merit.

ot Connecticut requires registration only of mining and oil securities. New York requires the filing of a simple form of notice prior to sale of non-exempt securities. Connecticut, Maryland and New York require registration of dealers.

${ }^{20}$ Secs. 3, 10.
} 
filing a notice of intention to sell together with certain information respecting the issuer, nature of its business, capitalization, and purposes to which the proceeds are to be applied. Examination of the information filed is made from the viewpoint of prevention of fraud.

Registration is required in Nebraska, but the exemptions are liberal. The Bureau of Securities has the usual broad powers in passing on applications for registration. New Mexico and Wyoming have "speculative securities" type of statutes. In the former the exemptions are narrow and the commission has broad powers to deny registration on the ground of insolvency, unfair or unsound business of the issuer, fraud, etc. In Wyoming the exemptions are broad and consideration of the application is made with the objective of preventing fraud.

The Pennsylvania law requires dealers to file notices of intention to sell and thereafter information concerning the issuer and its securities. Here also sales are not prohibited unless evidence of fraud appears. Securities exempt under Section 3(a) of the Federal Securities Act, except Section 3(a)(II), are exempt in Pennsylvania. (This does not include the small offering exemption pursuant to S. E. C. regulation under Section $3(\mathrm{~b})$.) In Rhode Island notice of intention to sell must be filed and the Chief of the Division of Banking and Insurance may require filing of information respecting the issuer and the securities to be offered and may prevent sales which would be fraudulent or against public interest.

Texas requires an issuer's permit for non-exempt securities and the permit may be denied if the Secretary of State finds that the proposed plan of business is unfair, unjust or inequitable and that the sale would work a fraud on the purchaser. The law contains broad exemptions similar to those in the Uniform Act. In Virginia registration is required but the exemptions are also extensive. Registration may be denied for reasons relating to soundness of the business as well as for fraud. Washington requires the filing of an application for a permit but compliance is generally not burdensome. The permit must be issued if the issuer's business is fair, just and equitable and the securities and method of issuing and disposing of them are not fraudulent. Washington also has a specific statute covering metalliferous mining securities. The West Virginia statute follows somewhat the Uniform Act but is more restrictive. There is no provision for registration by notification and the commissioner may impose such conditions on the sale of securities as he deems necessary. The powers to deny or revoke registration are broad.

The costs of qualification of securities under state laws do not approach those of federal registration. Statutory fees vary widely but many states follow the pattern of the Uniform Act in requiring a fee of one-twentieth of one percent, with a minimum of around $\$ 10$ and maximum of $\$$ roo, for securities registered by notification and one-tenth of one percent, with a minimum of $\$ 20$ and maximum of $\$ 200$ for securities registered by qualification.

Statistics released by the S. E. C. indicate that the costs of state qualification are not tremendously burdensome. In the study covering preferred and common stock 
issues registered under the Securities Act during the period from January I, $193^{8}$ to June 30, $x 944$ the cost of state qualification of equity securities was shown to be around 0.17 percent of gross proceeds for companies with assets under $\$ 1,000,000$ included in the survey. ${ }^{96}$ Cost for preferred stock of such companies was 0.14 percent and for common stock 0.17 percent. ${ }^{97}$ For companies with assets between $\$ 1,000,000$ and $\$ 5,000,000$ state qualification costs were: all equity securities, o.12 percent, preferred stock, 0.08 percent and common stock, 0.I4 percent. $^{98}$

The degree of enforcement of state security laws varies widely among the states. In some the statutes are strictly applied while in others enforcement is nominal. The extent of the burden on small business financing in many instances turns upon this consideration.

On the whole it can be said that state security regulation does not seriously impede the financing of small business. If this were not so there would never have been the development of small enterprise to the extent that it exists today. In the more than thirty years that state securities laws have been in existence they have been found to be workable and desirable and not unduly restrictive on the efforts of small businesses to obtain needed capital.

\section{Summary and Conclusion}

The problem of the restrictive effect of security regulation on small business financing is one relating mainly to the federal law. While the complaints of small business have been exaggerated and the burdens have sometimes been more imaginary than real, there is no doubt that in many instances the financing of small enterprises has been impeded by the registration requirements of the Securities Act.

An important step toward solution of the problem has been the amendment of the statute to permit exemptions for issues up to $\$ 300,000$. Experience under the enlarged exemption will demonstrate whether, in the process of accommodating the interests of the businessman to those of the investor, it will be desirable to amend the law further to remove unnecessary obstructions to small financings.

${ }^{08}$ S. E. C. Statistical Series Release No. 744 (1944) Table 4.

${ }^{97}$ Ibid.

${ }^{\text {os Ibid. }}$ 